\title{
THE MAGICAL TECHNIQUE OF CHAMBA RUMAL
}

\author{
Dr. Gagan Gambhir ${ }^{1} ه$ \\ Associate Professor, Apeejay College of Fine Arts, Jalandhar, India
}

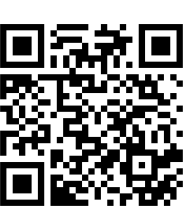

\section{ABSTRACT}

India is known for its textiles and embroidery all over the world. Indications of cotton fabrics have been found at the site of the Mohen-jo-Daro excavations and the finest muslins and silks are seen represented in the murals of the Ajanta and Bagh caves. The art of embroidery has been practiced since the remote ages in India. At the excavations made at Mohen-jo-Daro, bronze needles have been found which were most probably used for purposes of embroidery. Ancient literature and sculptures also prove the antiquity of the art of embroidery in India.

Keywords: Magical, Technique, Chamba Rumal

\section{INTRODUCTION}

Received 07 August 2021

Accepted 29 August 2021

Published 27 September 2021

Corresponding Author

Dr. Gagan Gambhir, gambhirg25@gmail.com

\section{DOI}

10.29121/shodhkosh.v2.i2.2021.33

Funding: This research received no specific grant from any funding agency in the public, commercial, or not-for-profit sectors.

Copyright: (C) 2021 The Author(s). This is an open access article distributed under the terms of the Creative Commons Attribution License, which permits unrestricted use, distribution, and reproduction in any medium, provided the original author and source are credited.

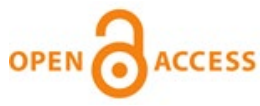

The craftsmen of India have always excelled in hand-embroidery on cotton, silk, wool, velvet, even leather and their creations have been the source of admiration. The Kashida embroidery of Kashmir, the darning stitch of Phulkari work of Punjab, both East and West, the chain stitch embroidery of Kathiawar, the double satin stitch of chamba, the silk embroideries of Banaras, the Kanthas of Bengal, the embroidered woolen shawls of Kashmir are some of the varieties of embroidery works done in India.

From the state of Chamba, originates, one of the most artistic, vivid and picturesque embroidery. This embroidery was done generally on the rumals (coverlets) used for covering the offerings to deities or as presents from bride's home to that of the bridegroom or vice-versa. Its principal utility was its usage as canopy in the temples; but this work of art was done at leisure by skillful housewives which remained the overall impelling force in their endless variety and finest of execution. "There are also few other assorted things such as fans, chaupar (a board game) spreads, pillow covers, basket covers etc., which featured a similar style of embroidery to that practiced on coverlets." Pathak (2010)

Art historians and scholars are of the opinion that the development of this traditional craft of embroidery started during the reign of Raja Umed Singh of Chamba (r. 1748-64). The craft continued to flourish under his successors Raj Singh (r. 1764-94). Jit Singh (r. 1794-1808). Charhat Singh (r. 1808-44) and Sri Singh (r. 1844-70). "The chamba rumal turns up in greater quantities first in the early reign of Charhat Singh..... The best rumals were made under Charhat Singh and his successor Sri Singh (r. 1844-70). Bhatia et al.(2009) 
The embroidered work of art ranges from variety of subjects; be it Religious, Mythological, Marriage Ceremonies, Hunting expeditions, Geometrical or floral patterns. The most fascinating aspect of these rumals is the depiction of vast subject theme, which is not usually found in any other kind of embroidered rumals. Pathak (2010) The earliest evidence of Chamba embroidery has been known to be the rumal made by Bibi Nanki and gifted to her brother on his marriage. This rumal is well preserved in Chola Sahib Gurdwara, Dera Baba Nanak, Gurdaspur District, Punjab. Bedi (n.d.).

The embroidery of Chamba was affected by a double satin stitch carried forward and backward alternately, done simultaneously on the two sides of the cloth, so that the space on both sides is filled up making the embroidered field on both faces appear equally effective and positive and similar in content. This is technically known as dorukha. As this satin stitch looks similar on both the sides of the fabric, wrinkles are formed. To avoid these wrinkles or puckers, the fabric is fitted tightly in the embroider hoop. This stitch is not easy to embroider as it looks. Generally, narrow and small size floral designs are selected for this stitch. Sometimes, big patterns are also embroidered in this stitch in a very peculiar way. This stitch is carried out in small lengths for big designs as shown.
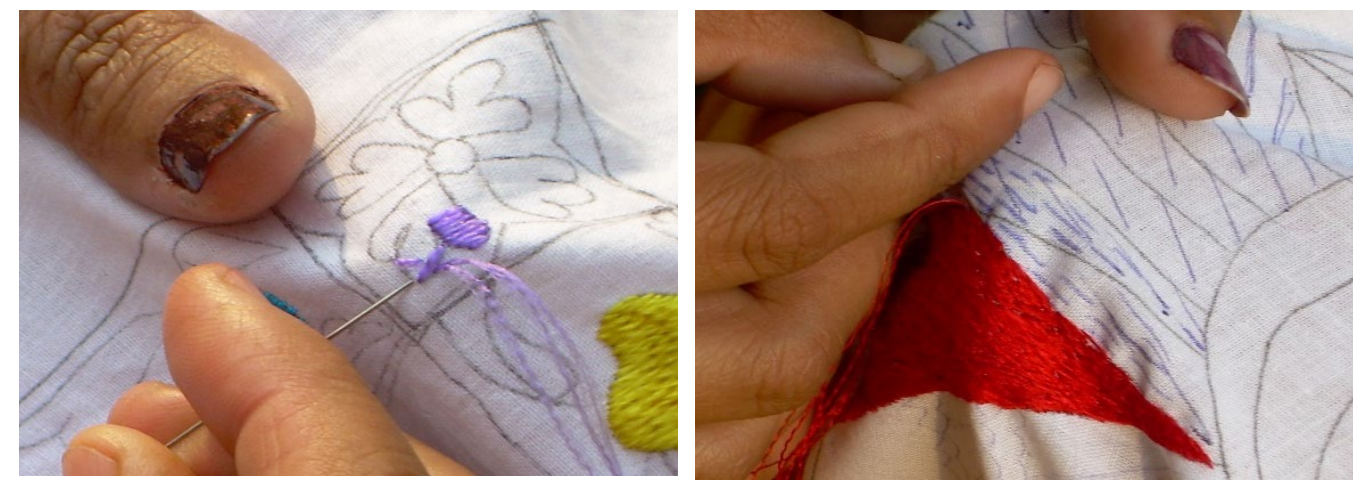

Figure 1 Double Satin Stitch

Source Author

In order to make neat and clean embroidery of this stitch, the design is outlined with running stitches. Long and short stitches are taken for solid filling in a design. That gives an embossed look to the design. As for the method of embroidering this stitch, first of all an outline of the design with the running stitch or the stem stitch is made. The needle is then brought from below upward at the beginning of the design. The needle is inserted from above downward at the other end of the double line. This process is repeatedly done. All the stitches are taken close to one another pulling the thread gently to avoid puckering. Ample care is taken so that the thread does not overlap at curves. This satin stitch is carried out by untwisted silk threads. Needles numbering 5 to 7 with a thin long eye are used for this stitch on a fine cotton muslin fabric. The colours for embroidery are chosen as per the design.

The satin stitch, which is generally resorted for covering large and continuous patterns spread over a variety of colours used in this kind of embroidery, leaves the figures and patterns smooth and glossy and equally graceful on both sides. The outline, drawn generally, in fine charcoal, used to be filled in with black silk threads in simple stem stitch, mostly in cases of patterns. More often, however, this kind of outline was absent. The enclosed ground was filled up with coloured threads. 

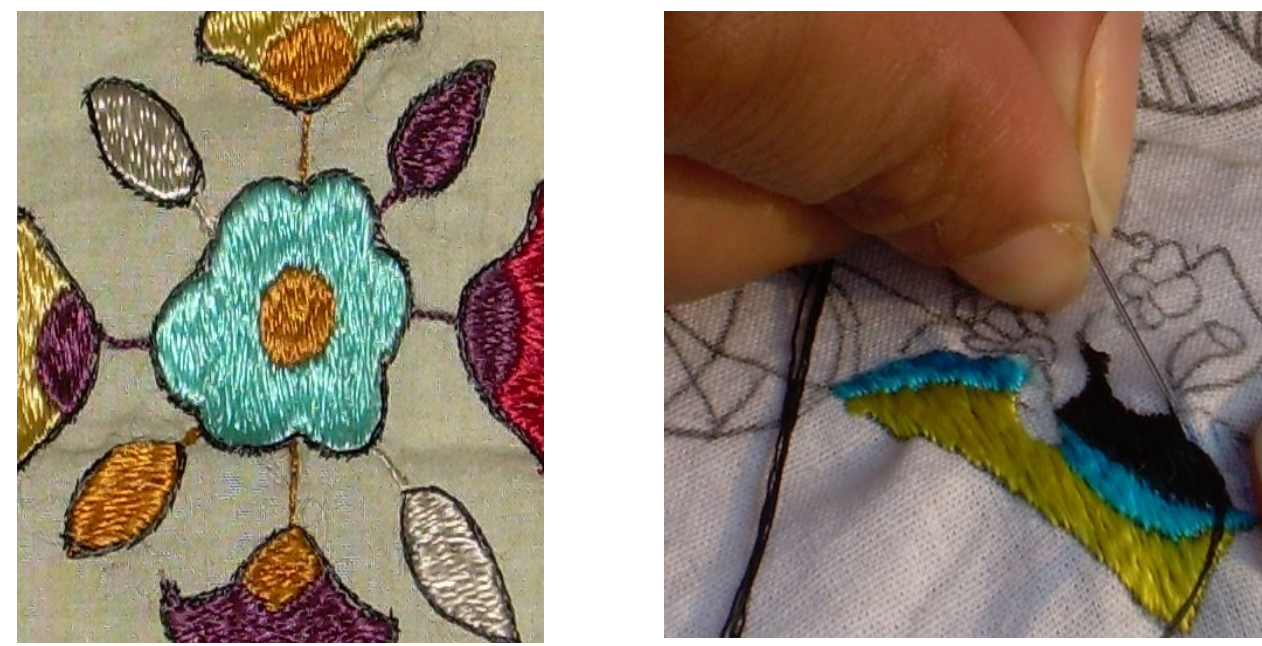

Figure 2 satin stitch

Source Author

In some cases of Chamba embroidery, the influence of phulkari technique and pattern from eastern Punjab is largely noticeable. In these phulkari types, the entire field of the rumal is covered up with floral patterns, the main content of which is geometrical and therefore, stylized and formal. The similarity of these lies not only in the pattern or the technique itself, but also in the fact that the base is coarse khaddar in both cases, and the yarns are untwisted silk of deep yellow, white, orange, red and blue. The designs common to phulkari and Chamba rumals brought about by horizontal, vertical and diagonal stitches have distinctive names, of which bagh or the garden design rectangular in layout are mostly in common use. The cloth for Chamba rumal is a kind of mal-mal handspun thin fabric which was manufactured in Punjab. The delicate and thin threads were made in Sialkot, Amritsar and Ludhiana. Different varieties of cloth were also used as the base for phulkari, i.e. the khaddar, hand-woven and handspun yarn. In later specimens with less artistic merit, machine-made fine cloth was used, but the older cloth was generally unbleached.

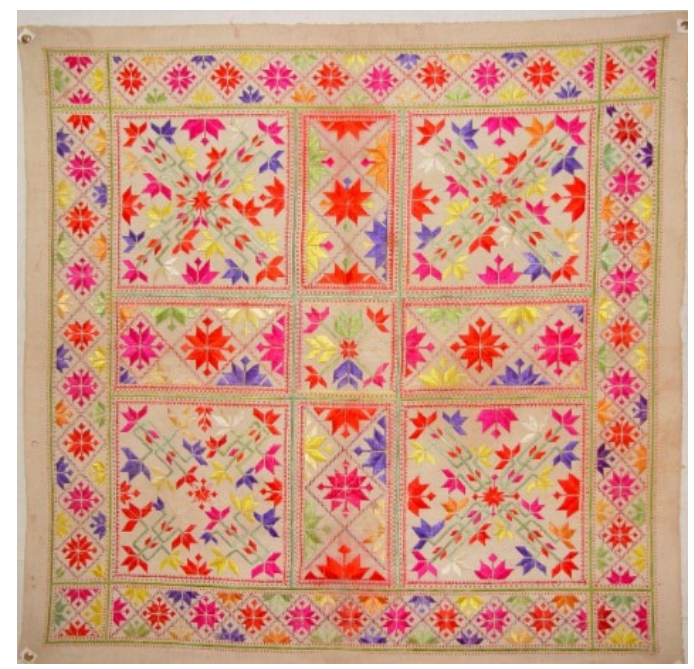

Figure 3 Floral Patterns Collection: - Indian Museum, Kolkata 
The pencil drawing of the figures, scenes or patterns were drawn, generally, by trained artists as may be guessed from some of the motifs and compositions of these embroidered rumals revealing features and characteristics strikingly common to contemporary paintings of the Pahari School with a known touch of lyricism. In these miniature compositions on cloth through embroidery the consummate hand of the Pahari artists is easily discernible in the balance and the harmony of colours.

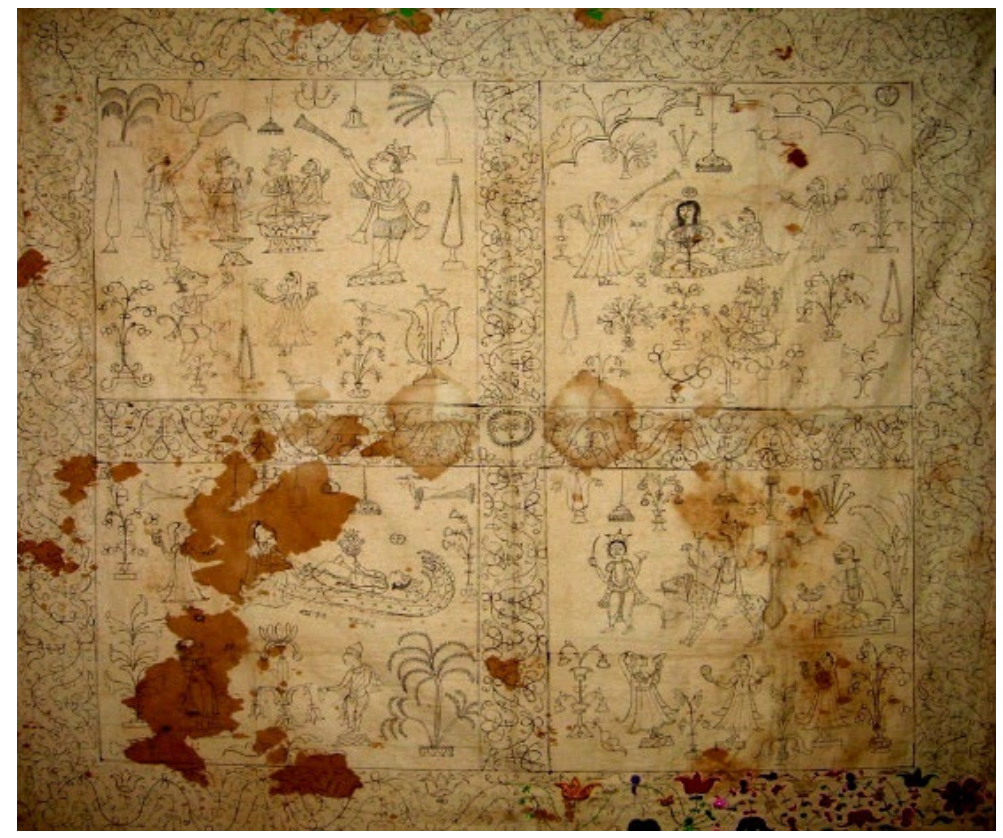

Figure 4 Pencil Drawing Collection: Bhuri Singh Museum, Chamba

The choice was mostly indicated by the artist, which the embroiderers were given to follow up with coloured threads. The soft flowing lines of both flowers and figures of background vegetation, hills, trees and shrubs all recall the miniature compositions in the great Pahari styles. Even the borders in their typical decorative pattern of the meandering flowers are clearly taken almost from the Pahari miniature, especially of the Kangra qalam. In the formal patterns, the adoption of the elliptical frame, so usual with Kangra painters, in a few cases brings it closer to classical Pahari styles. In content the same Krishna lila themes, notably the Rasamandala and the divine flute player flanked by worshipping gopis form the subject matter of these rumals. The same floral abundance with the dreamy willow, the green plantain, and the same architectural background with similar accessories, accompany the figures shown in similar kind of dress. These leave us in no doubt as to the master minds of the painters that worked behind the beautiful compositions brought to colourful finish through the deft needle of the embroiderers.

Sometimes, the designs and motifs of some rumals depicting the same themes were drawn by embroiderers themselves. The treatment of form and colour in the rumals has traces of folk inspiration also and links them with the tradition of mudwall paintings (the mud-wall are usually painted in some parts of northern India before Diwali, the festival of lights for the worship of Hoi Mata, the mother of goddess). The highly stylized, bold and vital figures and symbolic motifs such as tulsi plant, the sun, the Moon, birds and animals etc. embroidered in bright colours are very impressive and reveal an innate sense of design on the part of village women. 


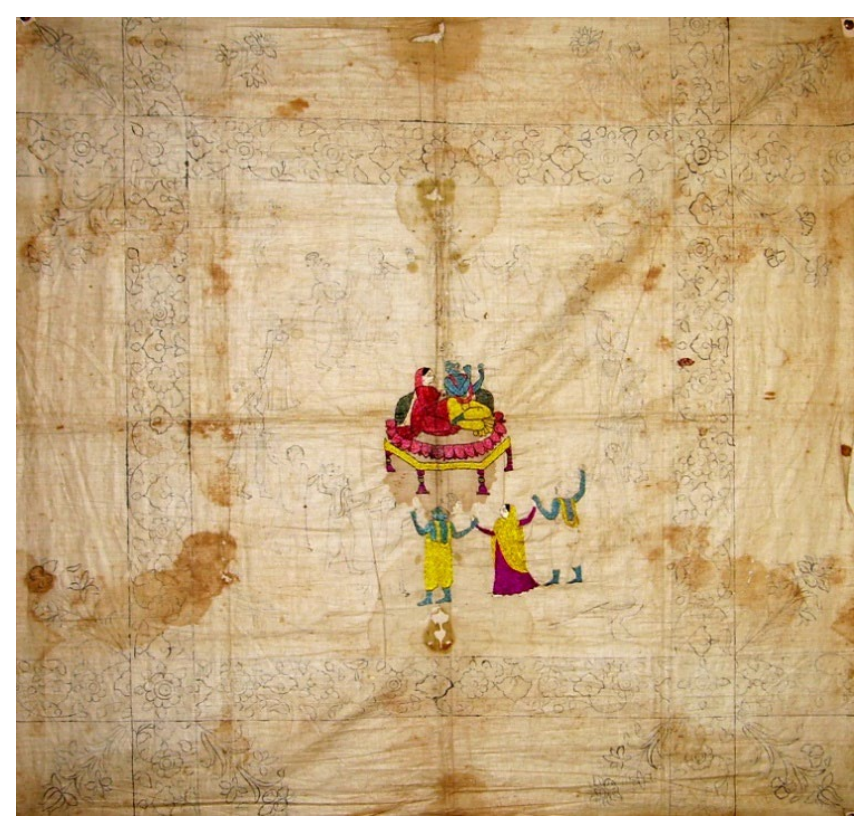

Figure 5 Collection: Bhuri Singh Museum, Chamba

In the development of the art of embroidery at least two or three stages in the technique may be recognized. A kind of small stitches in the double run is perhaps the earliest among these. The second stage is reached when the stitches appear long, though the back field which forms the negative side of the cloth appears equally glossy and smooth. A late stage is marked by the use of machine-made cloth. On the latter type of cloth, both, fine and coarser styles of embroidery is done. In the early specimens another technique followed is the inter-weaving of silver threads, ornaments, butis and border of garments. The threads used are greatly fibrous and boldly coloured. It is also quite possible that some of the rumals embroidered in the folk style are earlier in origin and that this style continued bilaterally with the sophisticated classical style contributed by the artists' drawing. However, brilliant pink and lemon yellow along with purple and moss green were favourites with folk designers, but these colours were changed to ochre yellow, dark green, red etc. by classical artists.

\section{REFRENCES}

\section{Bedi, K. S. (n.d.). 15th Generation of Guru Nanak Dev ji.}

Bhatia, U., Khanna A. N., Sharma, V. (2009). The Diverse World of Indian Painting (Essays In Honour of Dr. Vishwa Chander Ohri). Aryan Books International, New Delhi, 135, 143.

Pathak, A. (2010). Chamba Rumal : Embroideries of the Himalayan Region, Annals of the Naprstek Museum, 31(1), 90-91. 